US Army Corps of Engineers ${ }_{\circledast}$

Engineer Research and

Development Center

\title{
Analysis and Comparison of Documented Seepage and Sand Boil Events on the Lower Mississippi River from 1937 to 2011
}

Volume 3: Occurrences of seepage and sand boil incidents during the 2011 flood on photo maps

Joseph B. Dunbar, Amber L. Ensign, Nalini Torres, and Maureen K. Corcoran

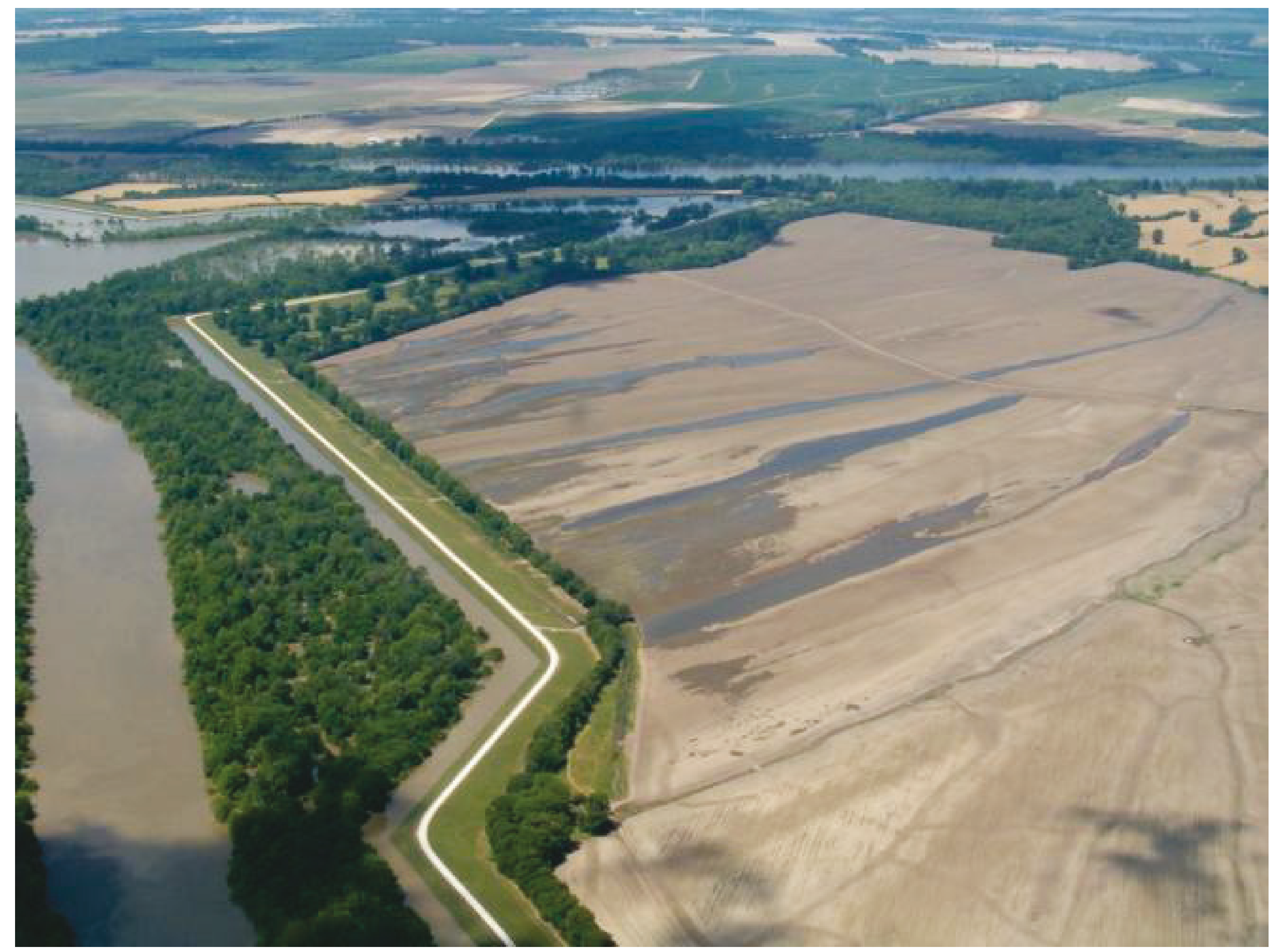


The U.S. Army Engineer Research and Development Center (ERDC) solves the nation's toughest engineering and environmental challenges. ERDC develops innovative solutions in civil and military engineering, geospatial sciences, water resources, and environmental sciences for the Army, the Department of Defense, civilian agencies, and our nation's public good. Find out more at www.erdc.usace.army.mil.

To search for other technical reports published by ERDC, visit the ERDC online library at http://acwc.sdp.sirsi.net/client/default. 


\section{Analysis and Comparison of Documented Seepage and Sand Boil Events on the Lower Mississippi River from 1937 to 2011}

Volume 3: Occurrences of seepage and sand boil incidents during the 2011 flood on photo maps

Joseph B. Dunbar, Amber L. Ensign, Nalini Torres, and Maureen K. Corcoran

Geotechnical and Structures Laboratory

U.S. Army Engineer Research and Development Center

3909 Halls Ferry Road

Vicksburg, MS 39180-6199

Report 3 of a series

Approved for public release; distribution is unlimited. 


\section{Abstract}

Volume III includes photo maps for ERDC/GSL TR-18-23; Volume 1, "Analysis and Comparison of Documented Seepage and Sand Boil Events on the Lower Mississippi River from 1937 to 2011," which examines the occurrence of seepage incidents and sand boils observed and documented during the 2011 Mississippi River Flood in the Lower Mississippi River Valley (LMV) within the boundaries of the U.S. Army Corps of Engineers (USACE), Mississippi Valley Division (MVD), Vicksburg District. This study examines the occurrence of sand boils in relationship to the underlying floodplain geology and identifies locations where large sand boils occurred. Large sand boil areas will be the focus for additional detailed study to better understand the mechanics of underseepage and internal erosion in USACE flood-control levees. Seepage and sand boil incidents documented during the 2011 Flood are presented in this report on geologic base maps and preflood imagery to compile a record of their occurrence and identify geologic relationships, as well as spatial patterns associated with the underlying fluvial landforms. A review of levee evolution within the LMV is summarized here along with past research studies of seepage involving major historic floods and their control.

DISCLAIMER: The contents of this report are not to be used for advertising, publication, or promotional purposes. Citation of trade names does not constitute an official endorsement or approval of the use of such commercial products. All product names and trademarks cited are the property of their respective owners. The findings of this report are not to be construed as an official Department of the Army position unless so designated by other authorized documents.

DESTROY THIS REPORT WHEN NO LONGER NEEDED. DO NOT RETURN IT TO THE ORIGINATOR. 


\section{Preface}

This study of the 2011 Mississippi River flood was conducted under the Infrastructure Technology Program, Flood and Coastal Storm Damage Reduction Program (FCSDR), in the research focus area for Improving Flood Risk Management and Water Control Infrastructure Resiliency and Reliability (WCIRR). Dr. Julie D. Rosati, U.S. Army Engineer Research and Development Center (ERDC), Technical Director, Coastal and Hydraulics Laboratory (CHL) was the Program Manager for FCSDR.

This study was conducted by personnel of the Geotechnical and Structures Laboratory (GSL). Dr. Michael Sharp, Technical Director, and Dr. Maureen K. Corcoran, Associate Technical Director, provided general supervision for this study. Dr. Joseph B. Dunbar, Geotechnical Engineering and Geosciences Branch (GEGB) of the Geosciences and Structures Division (GSD), was the principal investigator for this study of levee seepage and sand boil occurrence in the Vicksburg Engineer District during the 2011 flood. At the time of publication, Mr. Chris Price was Acting Chief, GEGB; Mr. James L. Davis was Chief, GSD. The Deputy Director of ERDC-GSL was Dr. William P. Grogan and the Director was Mr. Bart P. Durst.

COL Ivan P. Beckman was the Commander of ERDC, and Dr. David W. Pittman was the Director. 


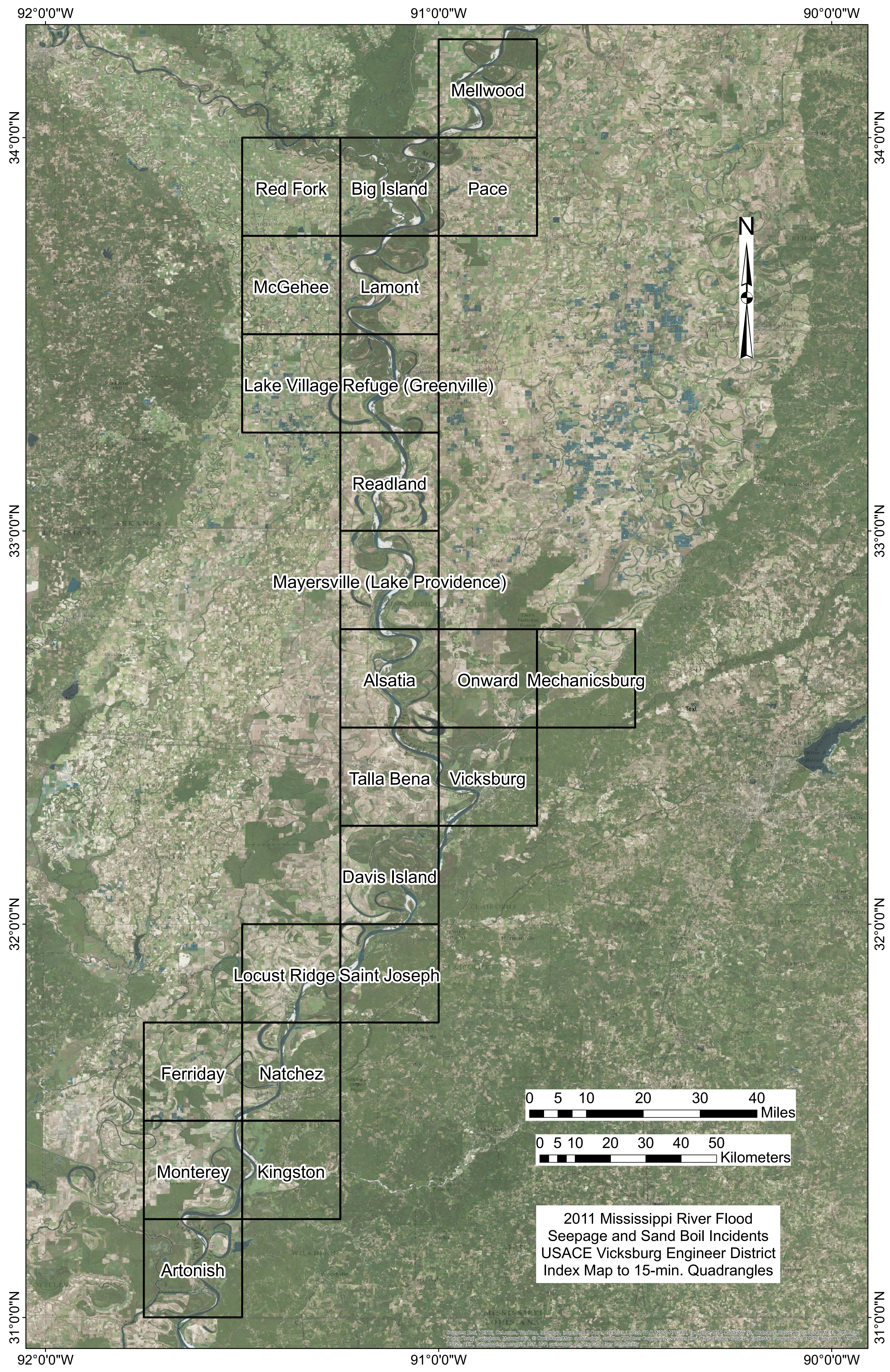




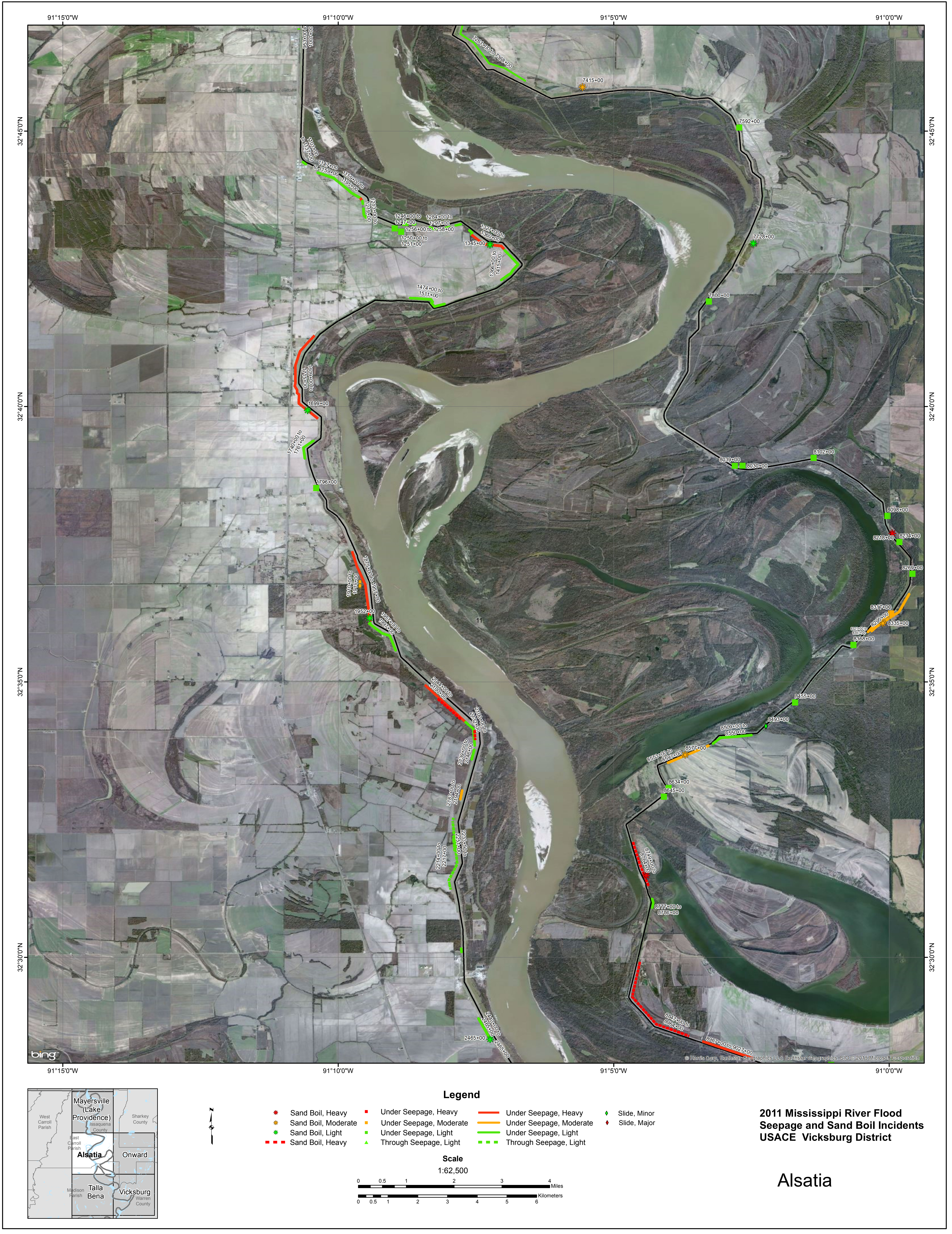




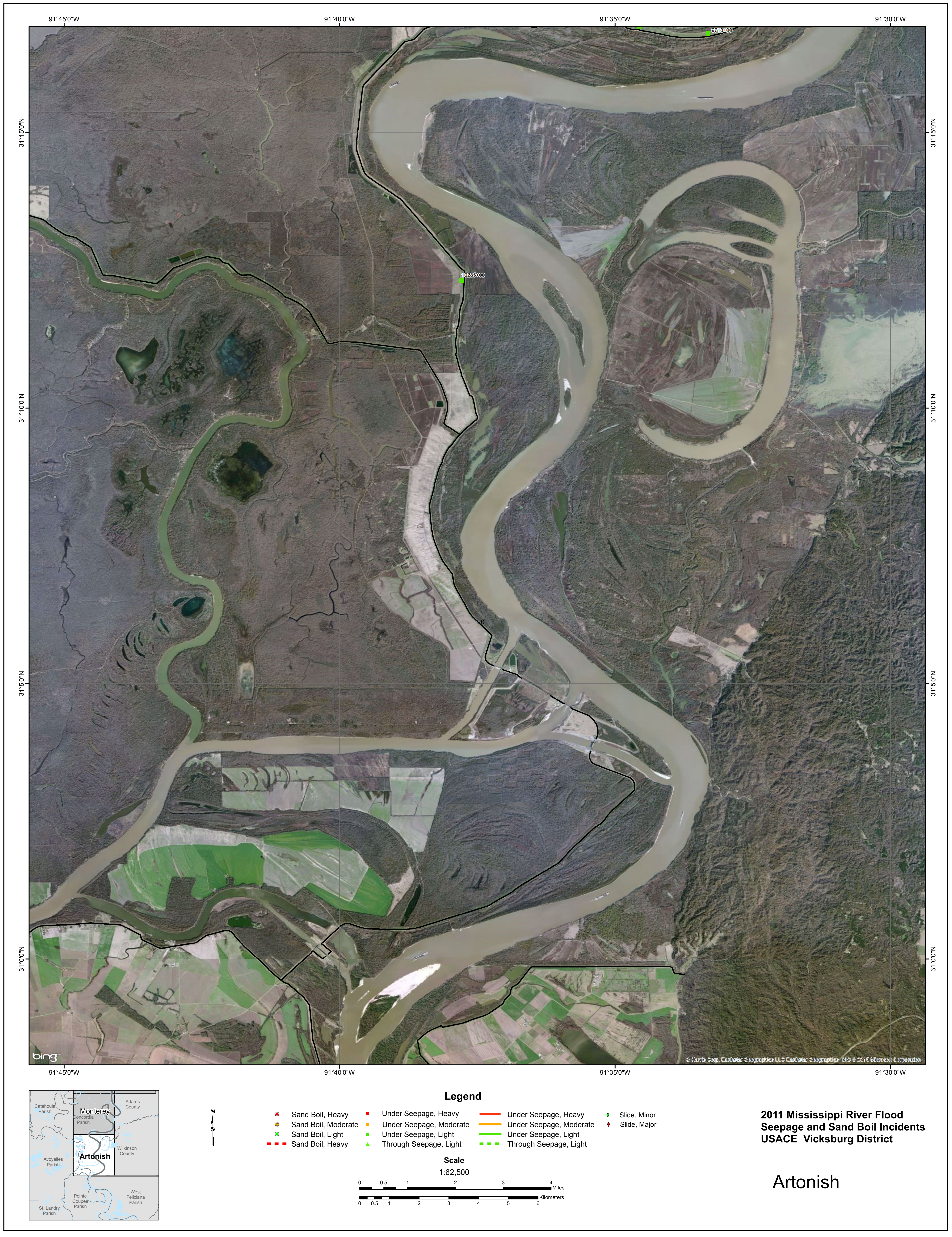




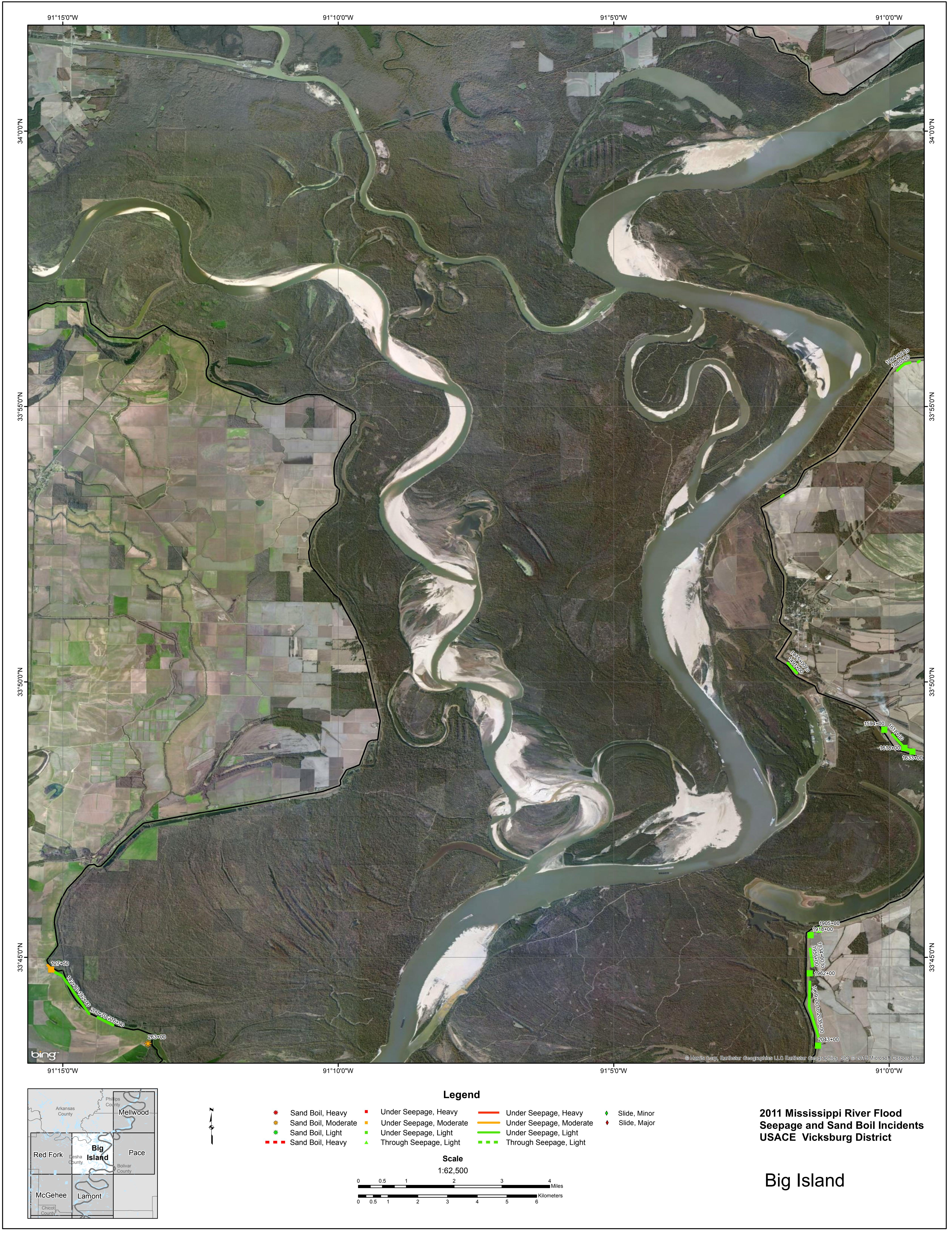









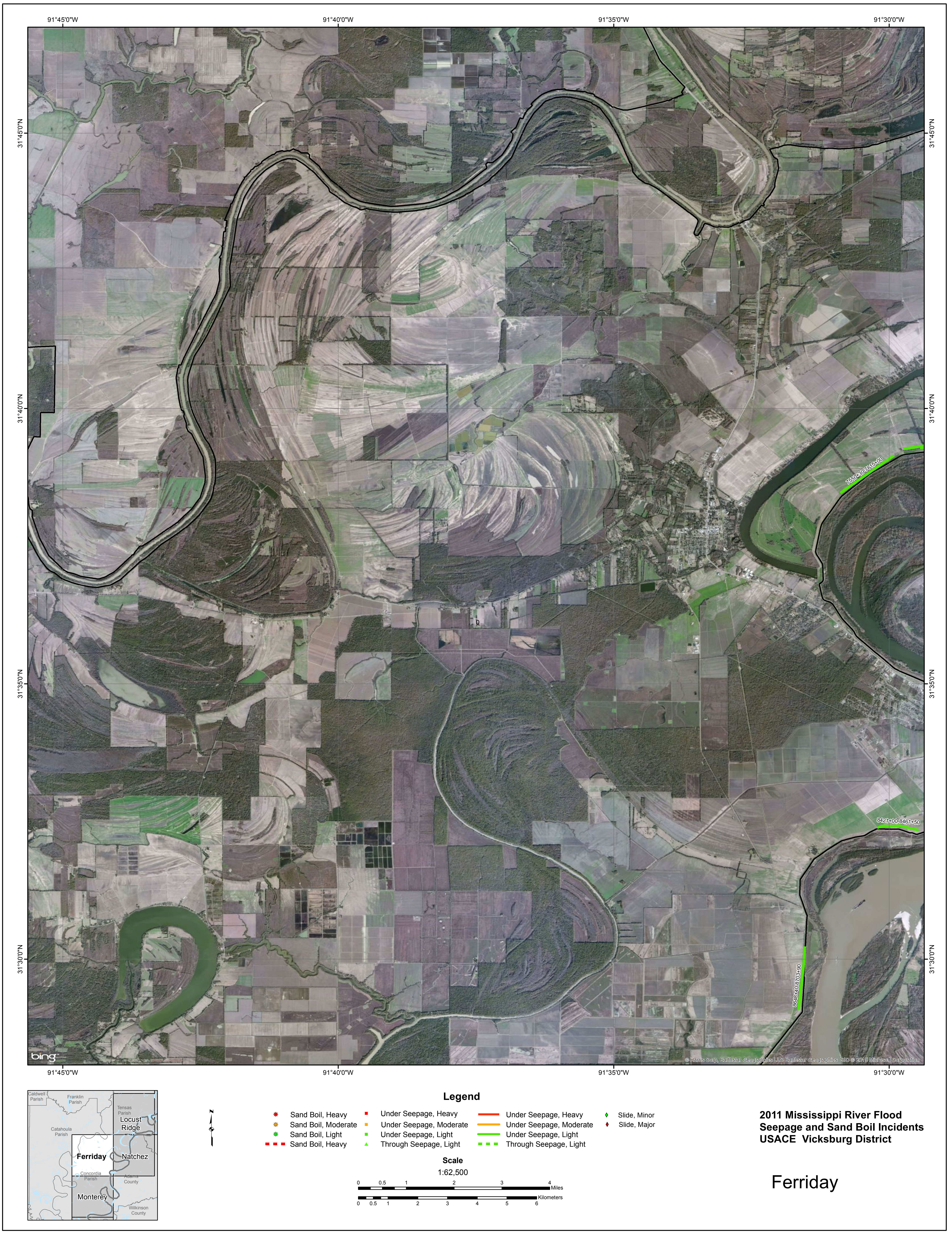




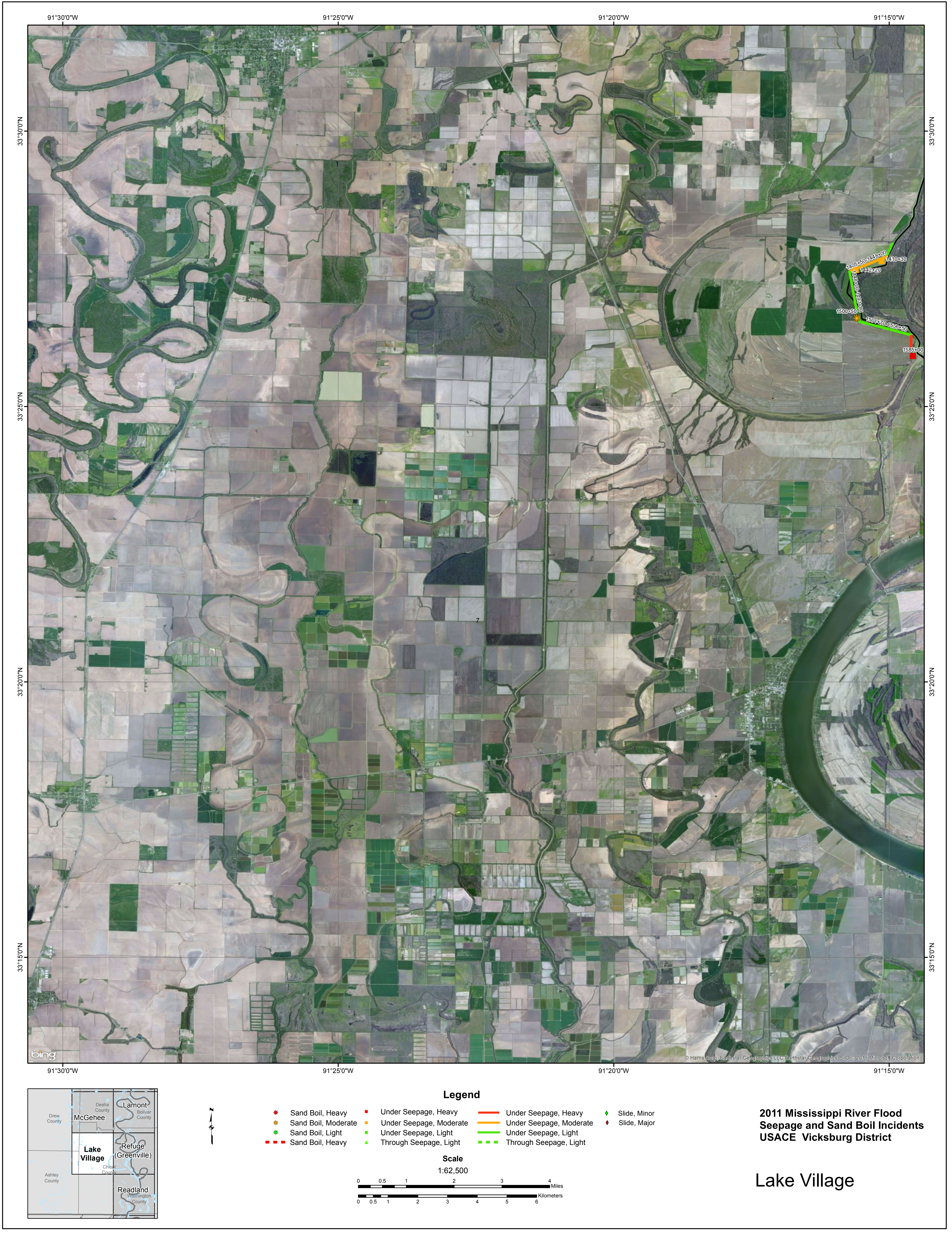




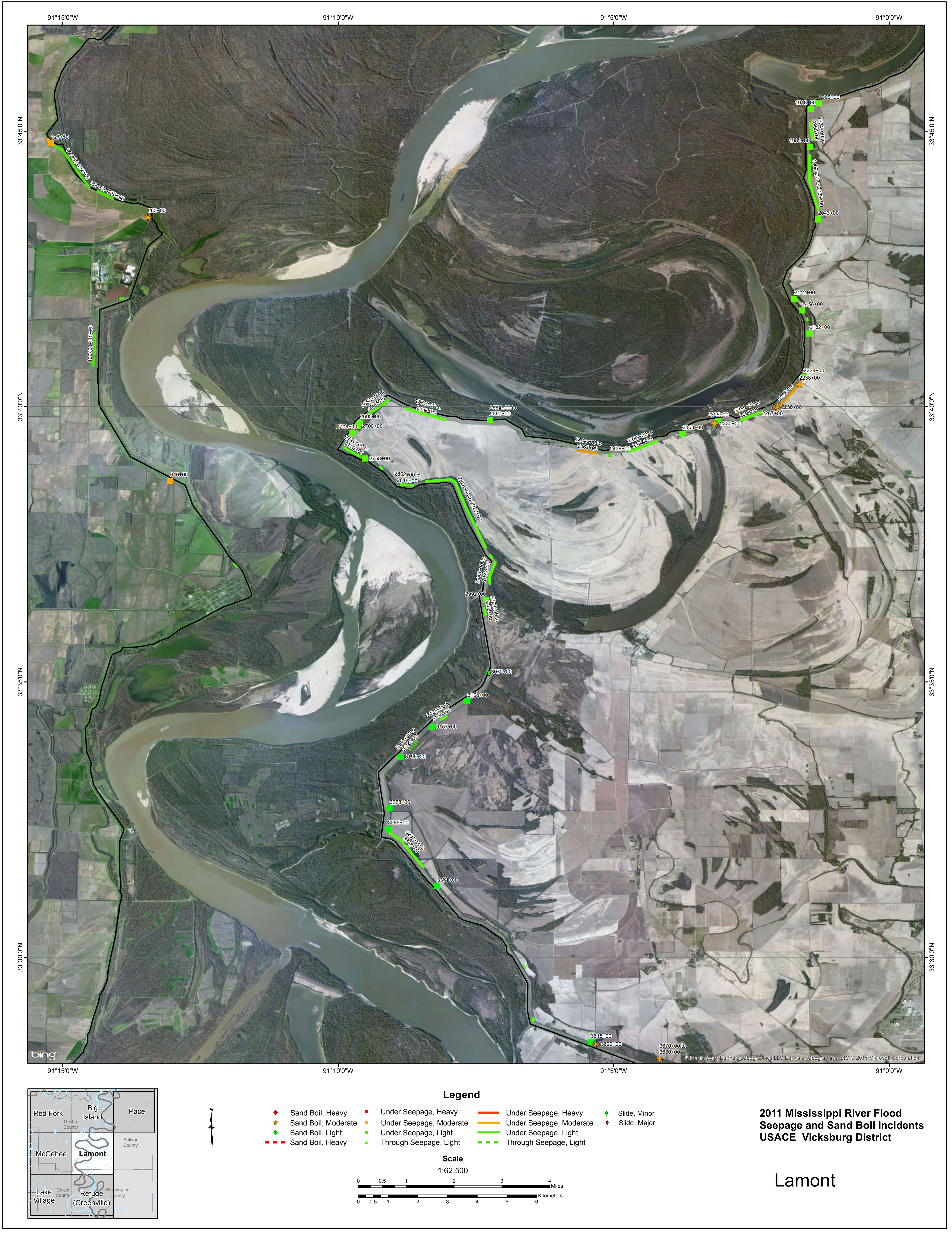




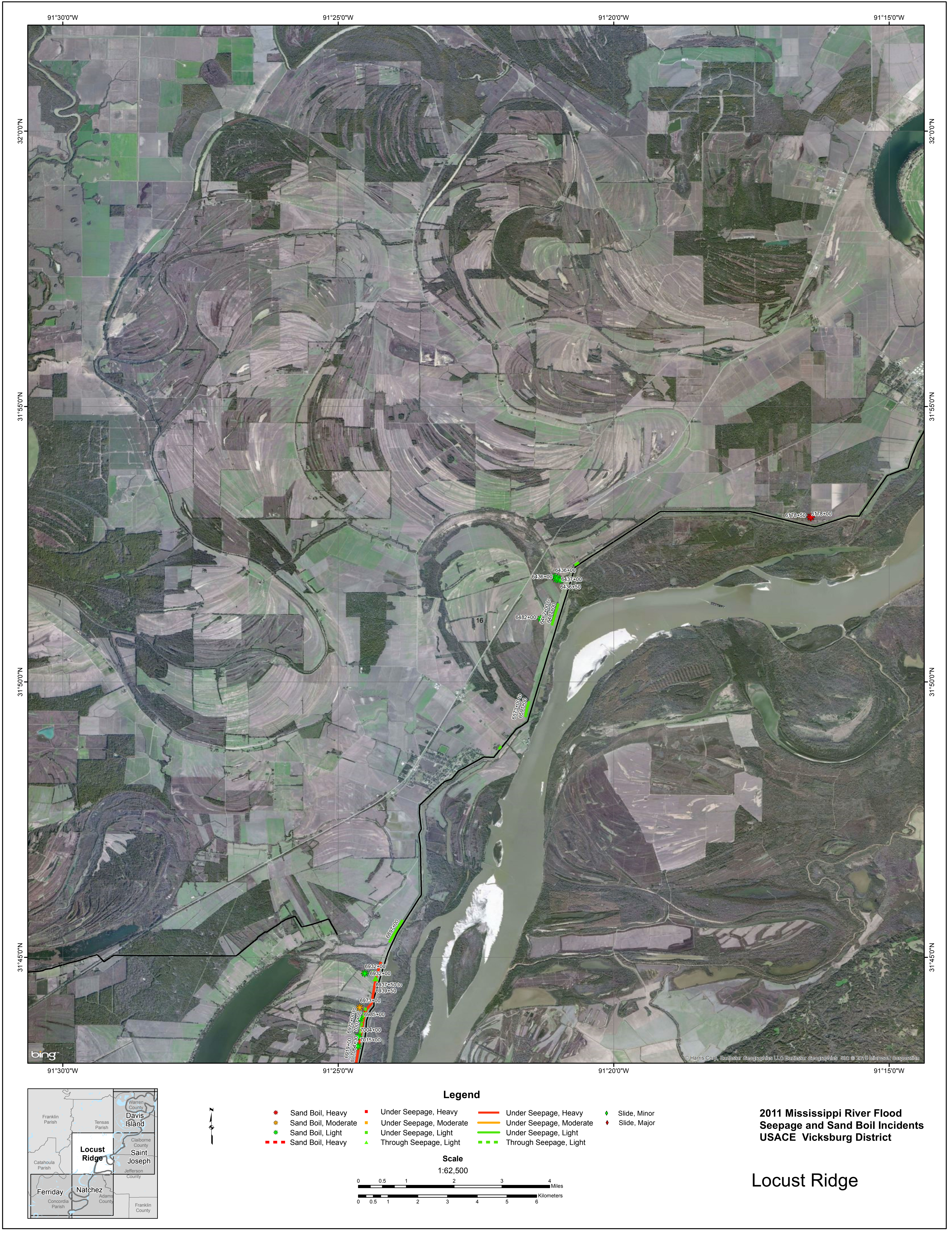









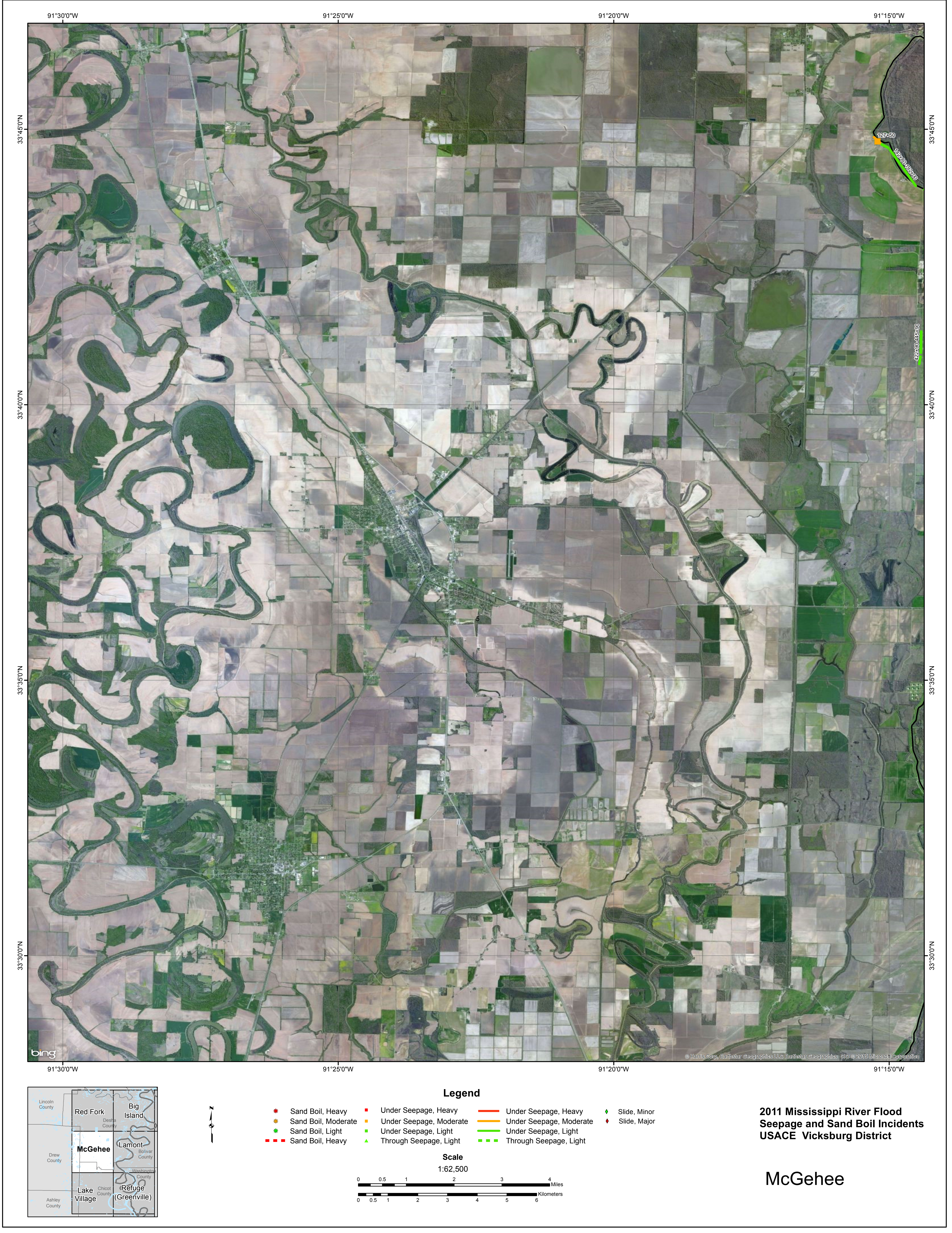




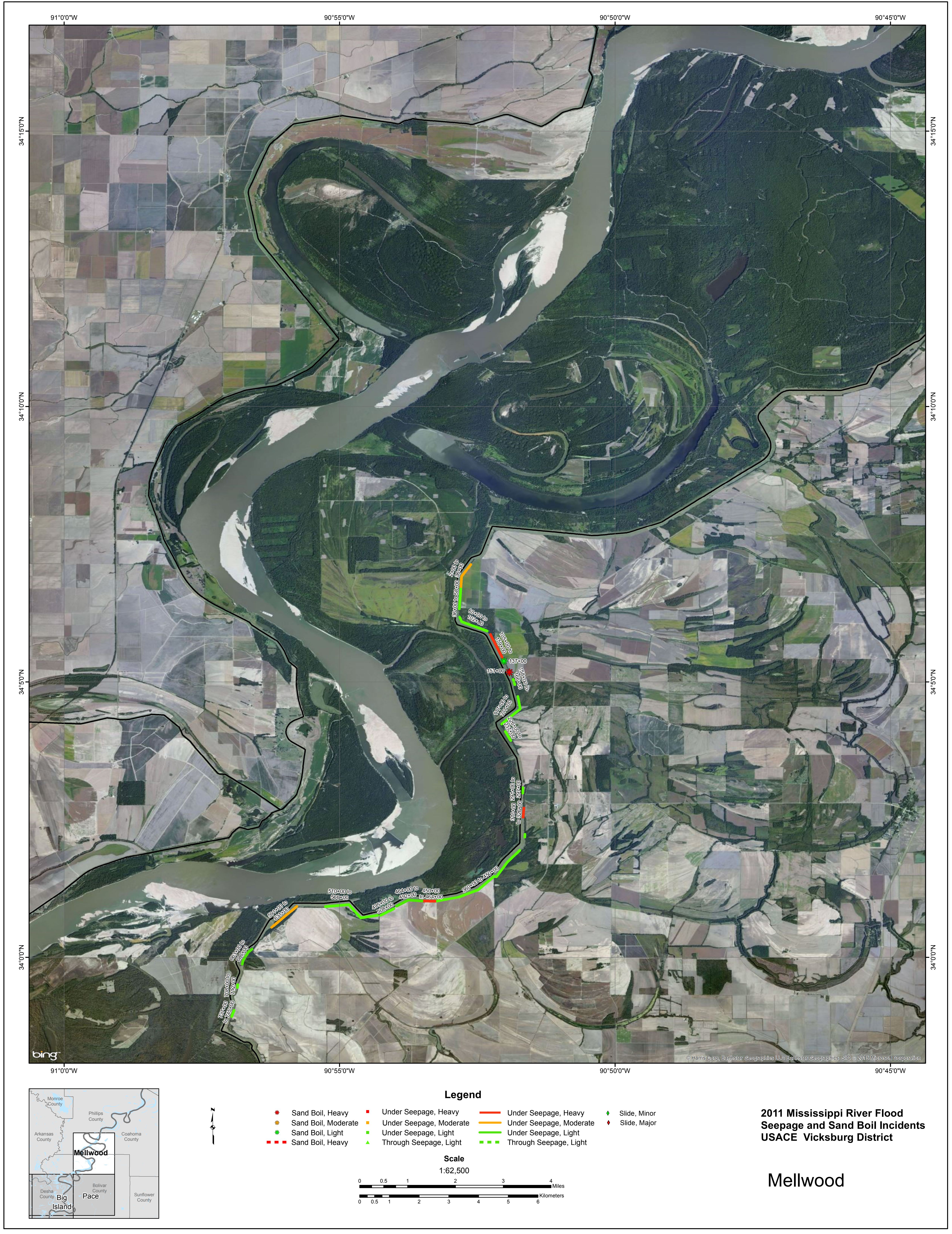




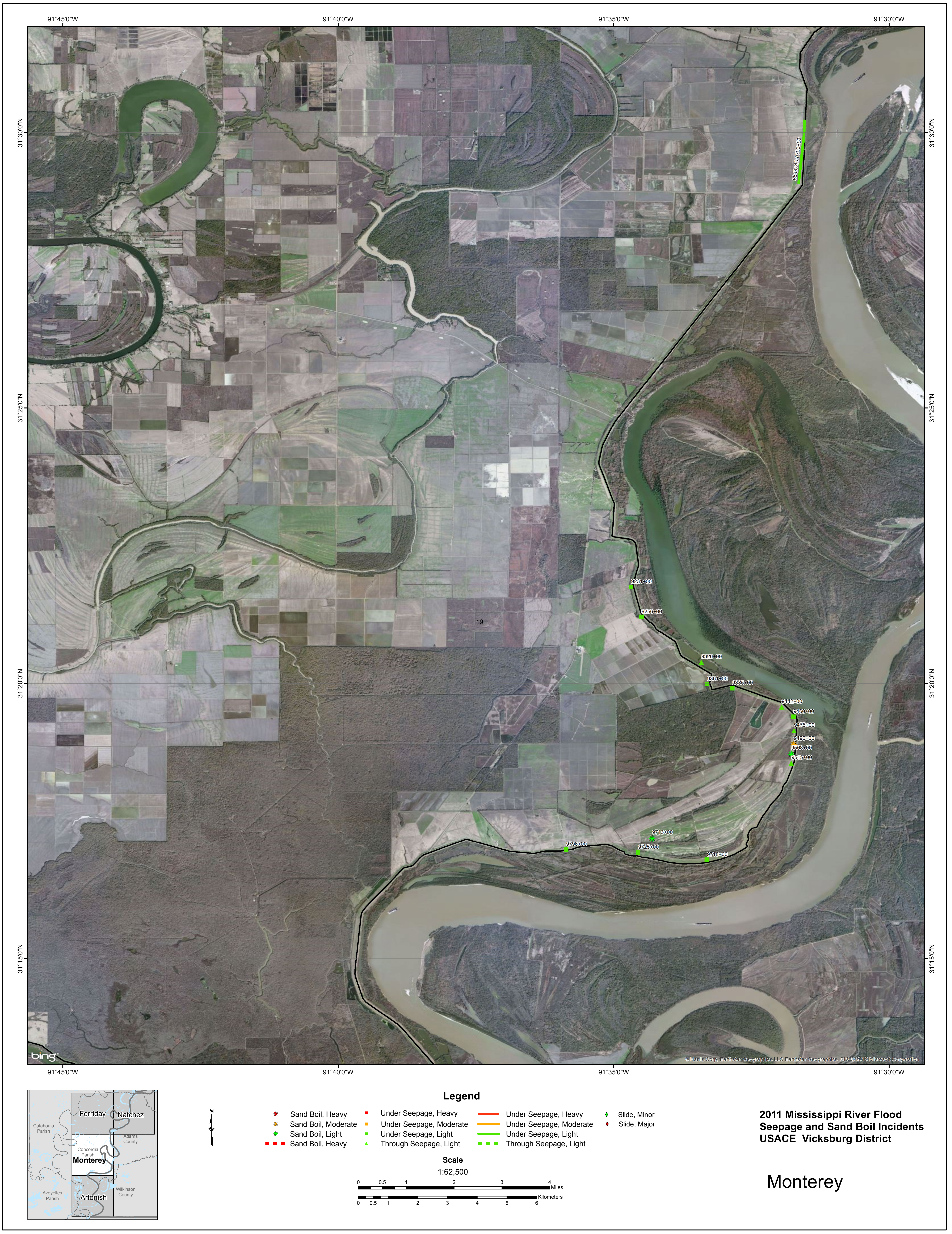
























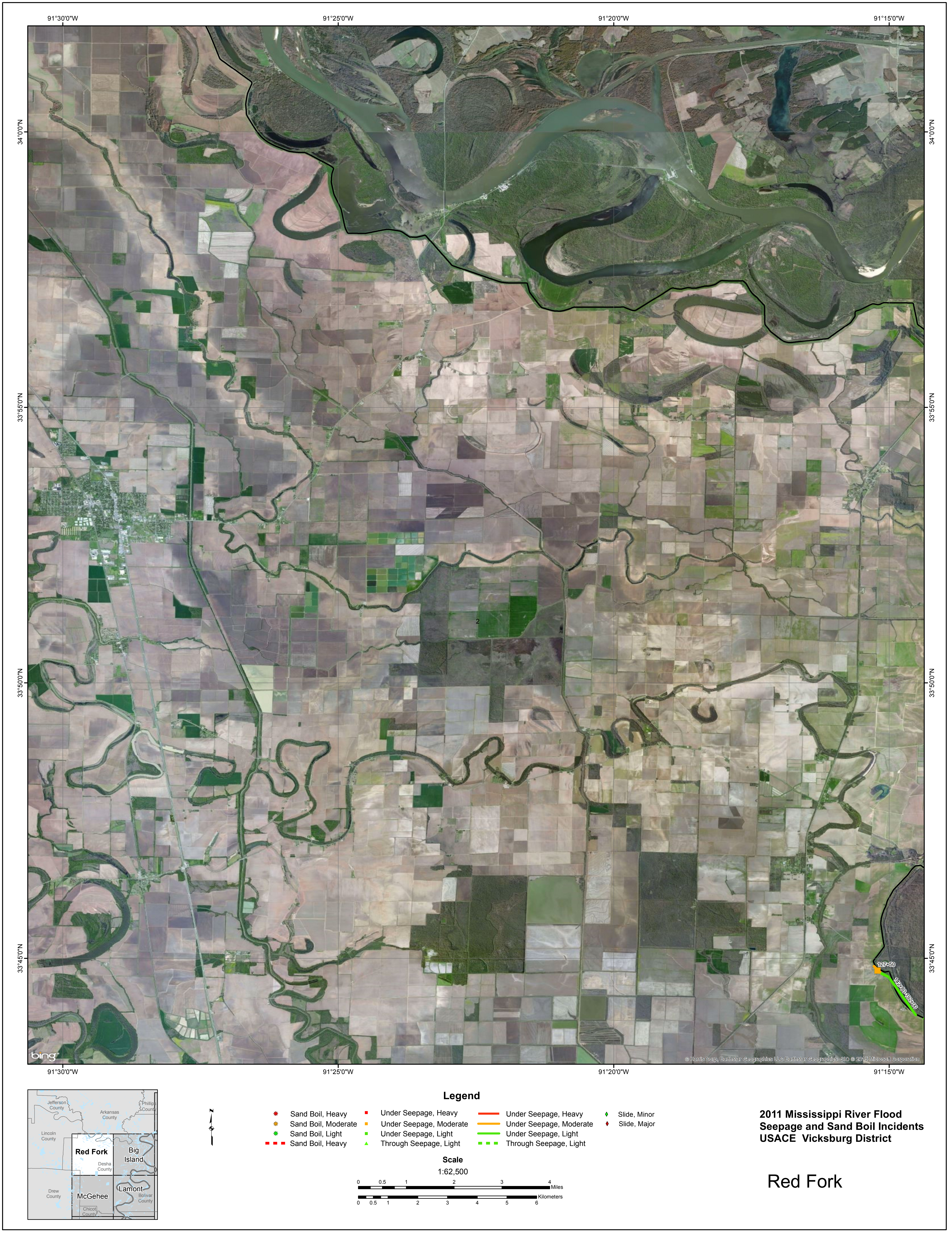




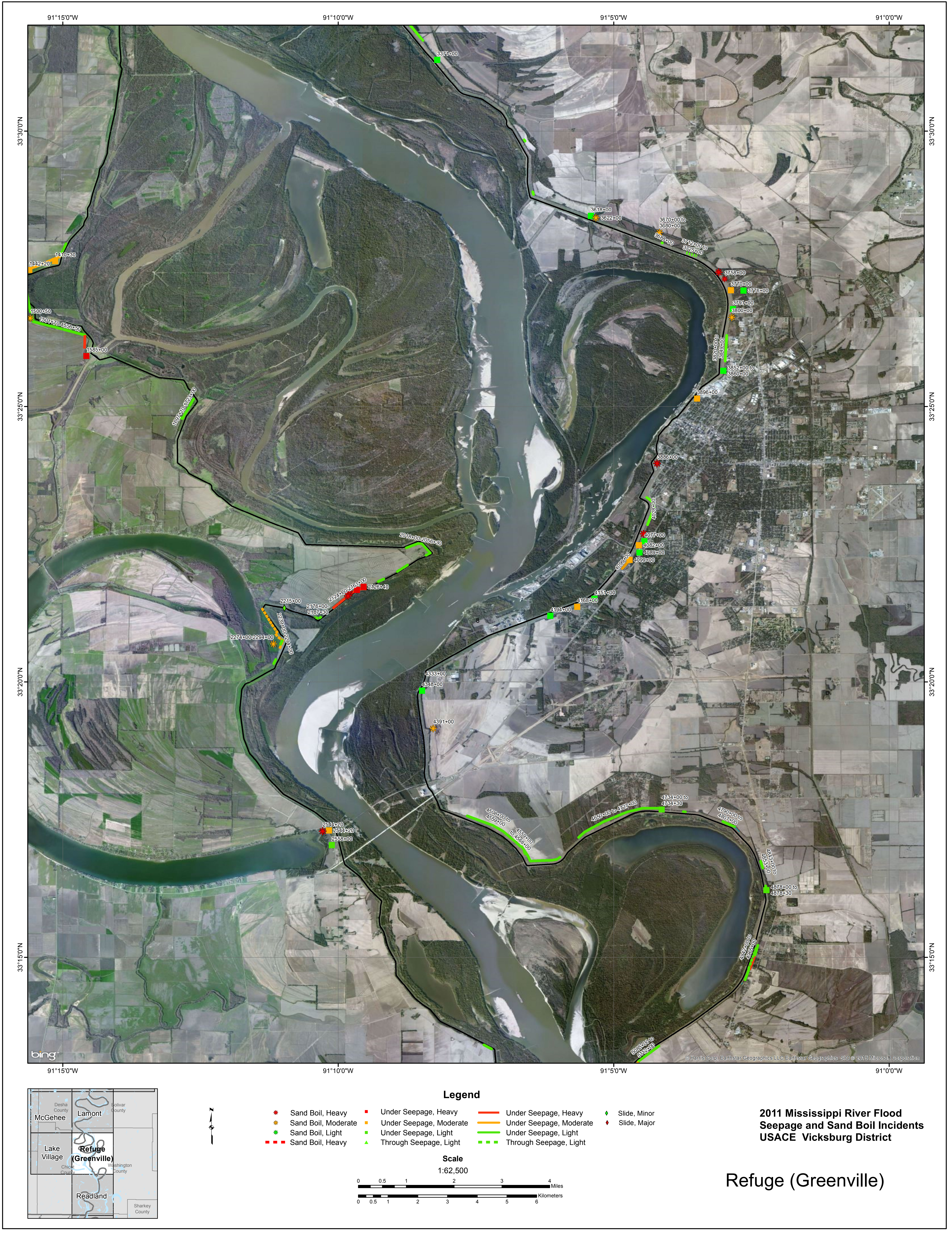




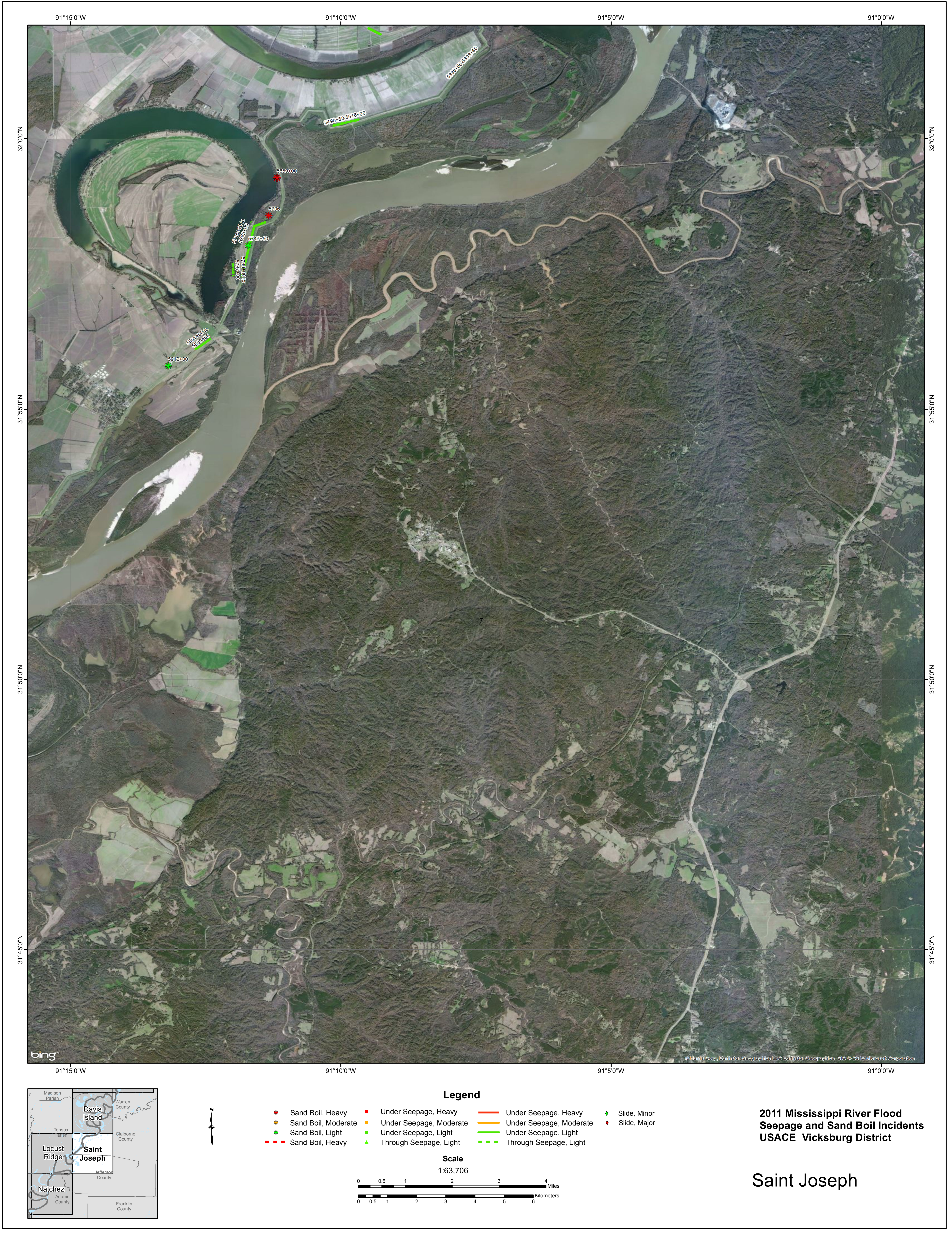




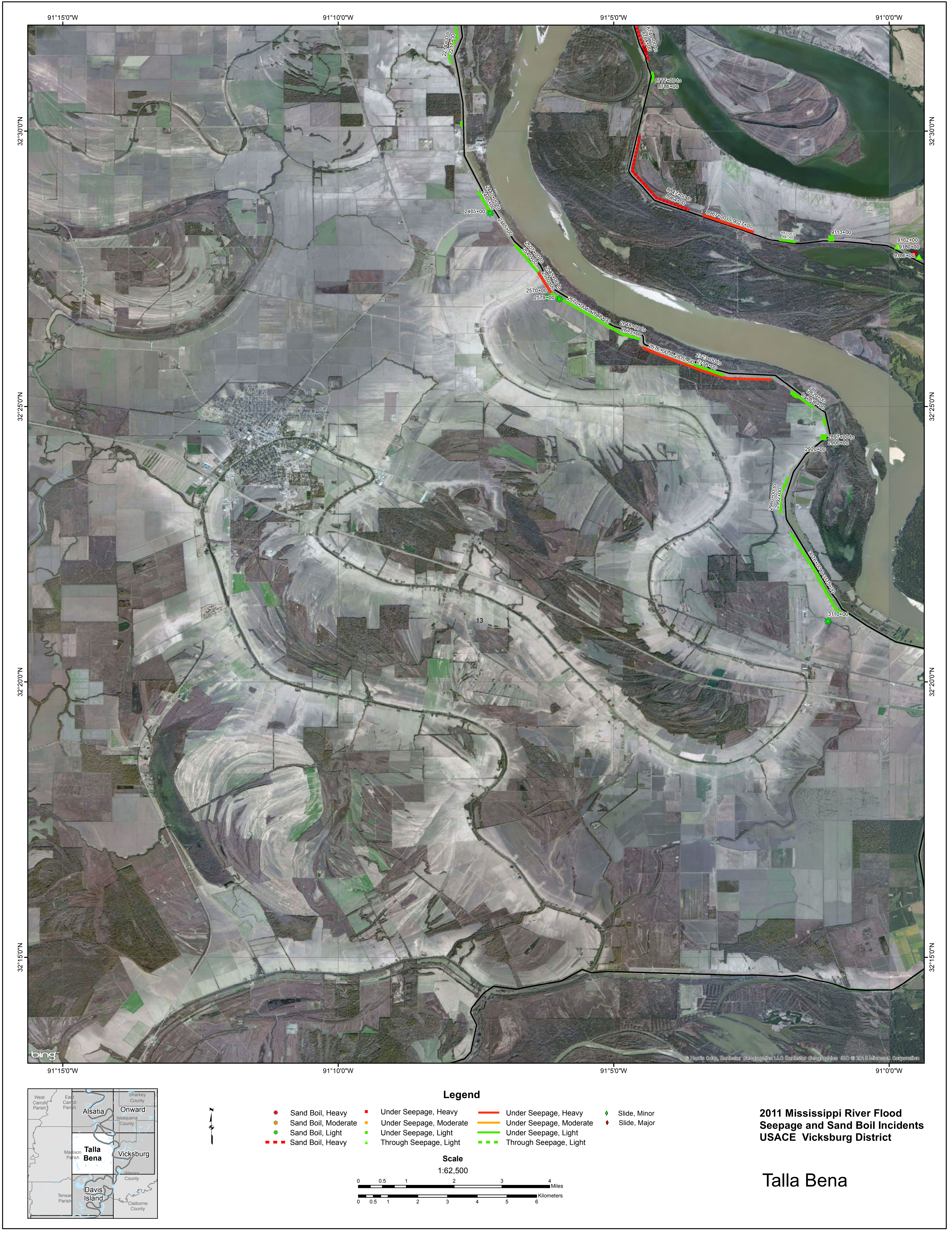




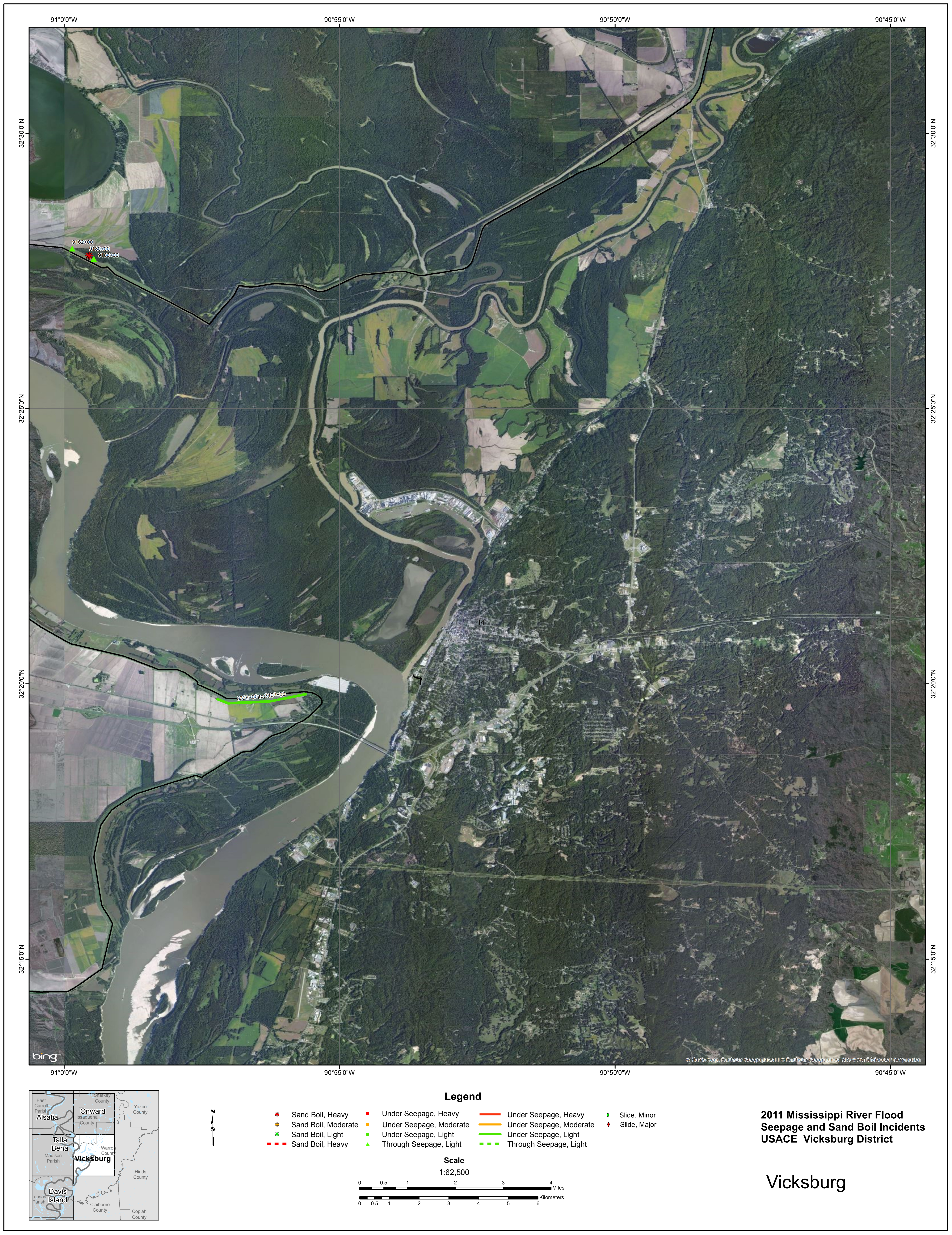


Public reporting burden for this collection of information is estimated to average 1 hour per response, including the time for reviewing instructions, searching existing data sources, gathering and maintaining the data needed, and completing and reviewing this collection of information. Send comments regarding this burden estimate or any other aspect of this collection of information, including suggestions for reducing this burden to Department of Defense, Washington Headquarters Services, Directorate for Information Operations and Reports (07040188), 1215 Jefferson Davis Highway, Suite 1204, Arlington, VA 22202-4302. Respondents should be aware that notwithstanding any other provision of law, no person shall be subject to any penalty for failing to comply with a collection of information if it does not display a currently valid OMB control number. PLEASE DO NOT RETURN YOUR FORM TO THE ABOVE ADDRESS.

\section{REPORT DATE (DD-MM-YYYY) \\ 2. REPORT TYPE \\ August 2018}

\section{TITLE AND SUBTITLE}

Analysis and Comparison of Documented Seepage and Sand Boil Events on the Lower Mississippi River

from 1937 to 2011; Volume 3
3. DATES COVERED (From - To)

5a. CONTRACT NUMBER

5b. GRANT NUMBER

5c. PROGRAM ELEMENT NUMBER

5d. PROJECT NUMBER J8D2HJ

5e. TASK NUMBER

5f. WORK UNIT NUMBER

8. PERFORMING ORGANIZATION REPORT NUMBER

ERDC/GSL TR-18-23

U.S. Army Engineer Research and Development Center

Geotechnical and Structures Laboratory

3909 Halls Ferry Road

Vicksburg, MS 39180-6199

\section{SPONSORING / MONITORING AGENCY NAME(S) AND ADDRESS(ES)}

U.S. Army Corps of Engineers

Washington, DC 20314-1000

\section{DISTRIBUTION / AVAILABILITY STATEMENT}

Approved for public release; distribution is unlimited.

\section{SUPPLEMENTARY NOTES}

\section{ABSTRACT}

Volume III includes photo maps for ERDC/GSL TR-18-23; Volume 1, "Analysis and Comparison of Documented Seepage and Sand Boil Events on the Lower Mississippi River from 1937 to 2011," which examines the occurrence of seepage incidents and sand boils observed and documented during the 2011 Mississippi River Flood in the Lower Mississippi River Valley (LMV) within the boundaries of the U.S. Army Corps of Engineers (USACE), Mississippi Valley Division (MVD), Vicksburg District. This study examines the occurrence of sand boils in relationship to the underlying floodplain geology and identifies locations where large sand boils occurred. Large sand boil areas will be the focus for additional detailed study to better understand the mechanics of underseepage and internal erosion in USACE flood-control levees. Seepage and sand boil incidents documented during the 2011 Flood are presented in this report on geologic base maps and pre-flood imagery to compile a record of their occurrence and identify geologic relationships, as well as spatial patterns associated with the underlying fluvial landforms. A review of levee evolution within the LMV is summarized here along with past research studies of seepage involving major historic floods and their control.

\section{SUBJECT TERMS}

Levees - Mississippi River

Seepage
Flood control

Sand boils

Geology - Mississippi River Valley
16. SECURITY CLASSIFICATION OF:

\section{a. REPORT}

UNCLASSIFIED

\section{b. ABSTRACT}

UNCLASSIFIED c. THIS PAGE

UNCLASSIFIED
17. LIMITATION 18. NUMBER OF ABSTRACT OF PAGES

29 19a. NAME OF RESPONSIBLE PERSON

19b. TELEPHONE NUMBER (include area code) 